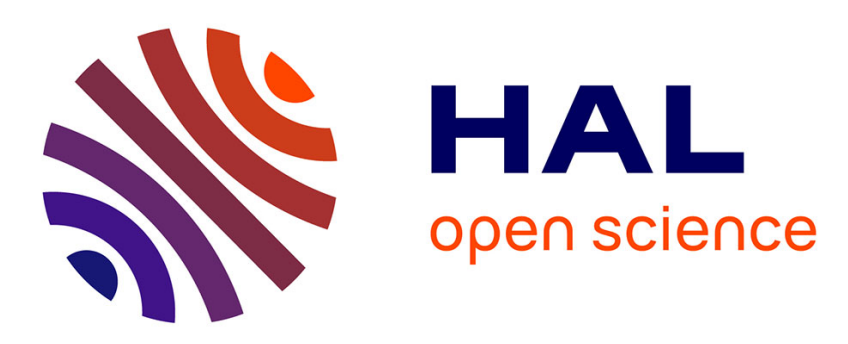

\title{
New taxonomic and phylogeographic data on three nominal species of the genus Septaria Férussac, 1807 (Gastropoda: Cycloneritida: Neritidae)
}

Ahmed Abdou

\section{- To cite this version:}

Ahmed Abdou. New taxonomic and phylogeographic data on three nominal species of the genus Septaria Férussac, 1807 (Gastropoda: Cycloneritida: Neritidae). Zootaxa, 2021, 4915 (1), pp.28-40. 10.11646/zootaxa.4915.1.2 . mnhn-03288213

\section{HAL Id: mnhn-03288213}

\section{https://hal-mnhn.archives-ouvertes.fr/mnhn-03288213}

Submitted on 16 Jul 2021

HAL is a multi-disciplinary open access archive for the deposit and dissemination of scientific research documents, whether they are published or not. The documents may come from teaching and research institutions in France or abroad, or from public or private research centers.
L'archive ouverte pluridisciplinaire HAL, est destinée au dépôt et à la diffusion de documents scientifiques de niveau recherche, publiés ou non, émanant des établissements d'enseignement et de recherche français ou étrangers, des laboratoires publics ou privés. 
New taxonomic and phylogeographic data on three nominal species of the genus Septaria Férussac, 1807 (Gastropoda: Cycloneritida: Neritidae)

\author{
AHMED ABDOU \\ Unité Biologie des organismes et écosystèmes aquatiques (BOREA), Muséum national d'Histoire \\ naturelle, Sorbonne Université, Université de Caen Normandie, Université des Antilles, CNRS, \\ IRD \\ CP 26, 57 rue Cuvier, 75005 Paris, France. \\ E-mail: ahmed.abdou@mnhn.fr
}

\begin{abstract}
Due to superficial morphological similarities, there is often confusion in the identification of some species of the genus Septaria. A combined analysis of the genital anatomy, morphometric and DNA, based on a portion of the COI gene, applied to three nominal species of this genus, confirmed the validity of Septaria tahitiana Eichhorst, 2016, and suggested that Septaria borbonica (Bory de Saint Vincent, 1804) is a subspecies of Septaria porcellana (Linnaeus, 1758), both taxa with disjunct distribution areas: Septaria borbonica in the western Indian Ocean and Septaria porcellana the western Pacific and eastern Indian Oceans. The possible presence of Septaria tesselata (Lamarck, 1816) in Mayotte (Comoros Archipelago) needs to be confirmed.
\end{abstract}

\title{
Résumé
}

En raison de similitudes morphologiques superficielles, il y a souvent confusion dans l'identification de certaines espèces du genre Septaria. Une analyse combinée, de l'anatomie de l'appareil génital, morphométrique et $\mathrm{ADN}$, basée sur une partie du gène $\mathrm{COI}$, appliquée à trois espèces nominales de ce genre, a confirmé la validité de Septaria tahitiana Eichhorst, 2016, et a suggéré que Septaria borbonica (Bory de Saint Vincent, 1804) est une sous-espèce de Septaria porcellana (Linnaeus, 1758), deux taxons dont les aires de répartition sont disjointes: Septaria borbonica dans l'océan Indien occidental et Septaria porcellana dans l'océan Pacifique occidental et l'océan Indien oriental. La présence possible de Septaria tesselata (Lamarck, 1816) à Mayotte (archipel des Comores) doit être confirmée.

Keywords: Indo-Pacific, shell morphometrics, mitochondrial DNA, taxonomy, phylogeny, mollusc

\section{Introduction}

Tropical island rivers are often subject to extreme climatic variations and seasonal hydrological variations (McDowall 2007; Crandall et al. 2010; Abdou et al. 2015). These freshwater ecosystems often represent isolated and fragmented habitats, colonized by a well-adapted fauna of molluscs, fish and crustaceans with a diadromous life cycle (Abdou et al. 2015), involving a mandatory marine phase. In the Indo-Pacific zone, the molluscs that are part of this fauna include estuarine and freshwater nerites of several genera.

Septaria Férussac, 1807 is one of the 16 genera of gastropod molluscs in the family Neritidae (Eichhorst 2016a). It is distinguished from the other neritid genera essentially by its 
internal operculum, a character unique in this family, its reduced columellar surface called septum, and its patelliform shell shape. The genus Septaria is supposedly comprises 14 species, including 11 freshwater species and three brackish water species. The latter three are Septaria clypeolum (Récluz, 1843) from the Philippines, Septaria livida (Reeve, 1856) from Vanuatu and Fiji and Septaria tesselata (Lamarck, 1816) from the West Pacific and the Indian Oceans. In her major revision of the genus Septaria, Haynes (2001) recognised 13 species, with $S$. clypeolum becoming a synonym of $S$. tesselata. The species of the genus Septaria are mainly found in tropical rivers in the Indo-Pacific zone. They presumably colonized the freshwater environment by multiple invasions from the sea (Kano et al. 2002). On the basis of morpho-anatomical characters, Haynes (2001) proposed a phylogenetic analysis tending to show that the genus Septaria is polyphyletic. However, this analysis is highly questionable because her phylogenetic tree does not support the alleged polyphyly. Instead, the tree shows an unresolved trichotomy at its base, a topology thatdoes not support the monophyly of the genus Septaria, but does not refute it either. To our knowledge, there has not yet been any molecular phylogeny of the genus that explored this issue.

Due to morphological similarities and given intraspecific variability, Septaria species have often been confused (Haynes 2001). Many authors have, for example, confused S. porcellana (Linnaeus, 1758) (Fig. 1A) and S. borbonica (Bory de Saint Vincent, 1804) (Fig. 1B), the type species of the genus. Indeed, these species are similar in appearance, but actually present both, morphological and anatomical differences (Haynes 2001; Eichhorst 2016b). In addition, their geographic distributions do not overlap, with $S$. borbonica occurring only in the Western Indian Ocean, where S. porcellana has never been found. Septaria tahitiana Eichhorst, 2016 (Fig. 1C) is a replacement name for $S$. taitana Mousson, 1869, this latter name being a nomen nudum as it appeared in an unpublished catalogue (Eichhorst 2016b: 837). Septaria tahitiana only occurs in French Polynesia and was long thought to be conspecific with $S$. porcellana (Pointier \& Marquet 1990; Resh et al. 1990, 1992; Liu \& Resh 1997; Bunje \& Lindberg 2007) because of its similar morphology. Yet, S. porcellana is not present in French Polynesia and more generally in the Central Pacific (Haynes 2001; Eichhorst 2016b).

The present contribution aims to shed new light on the taxonomy and phylogeography of S. porcellana, S. borbonica and S. tahitiana, using DNA sequence, morphometric and anatomical data. 

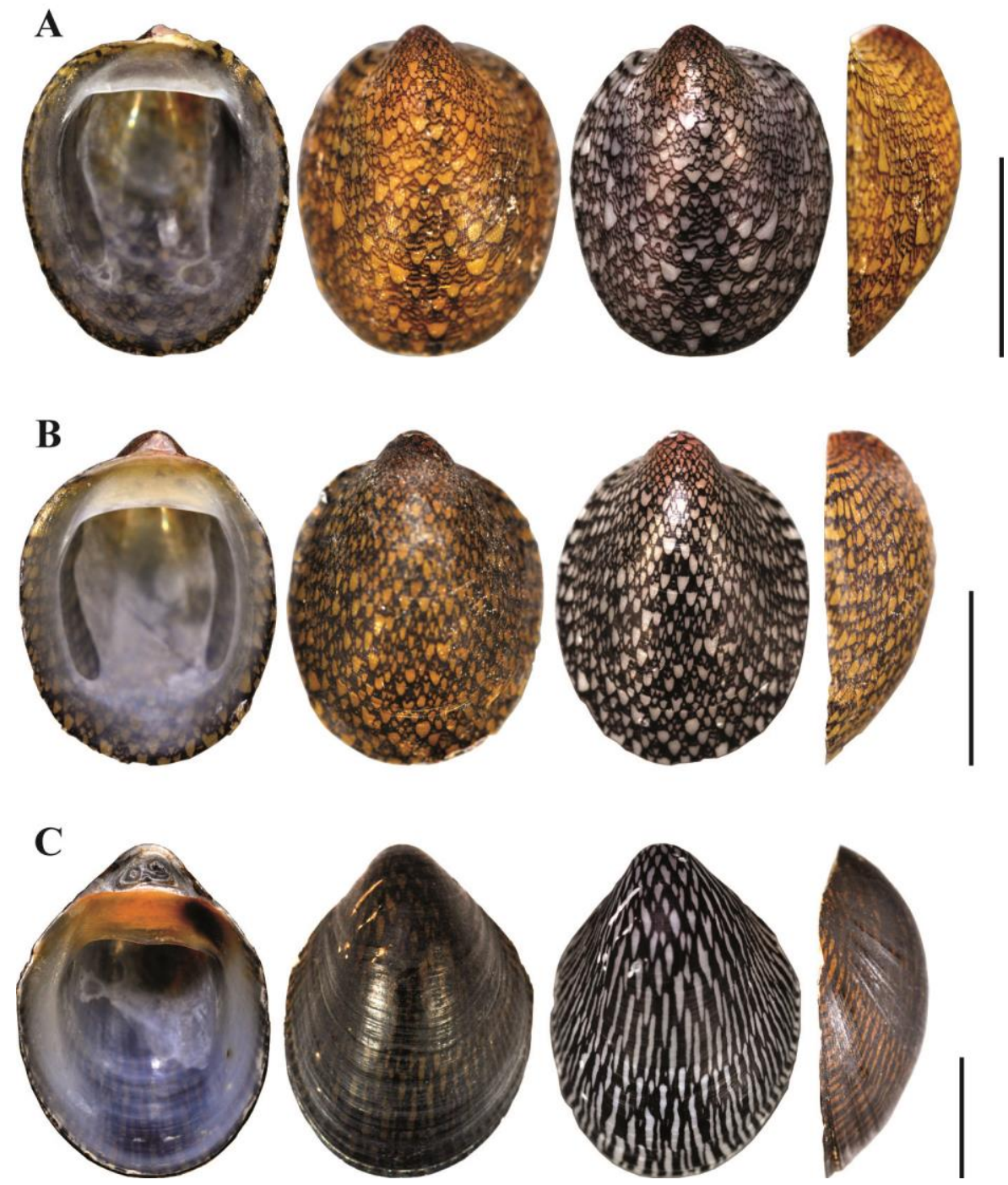

Figure 1. A Septaria porcellana (Linnaeus, 1758), MNHN-IM-2013-62871 (Okinawa, Japan) B Septaria borbonica (Bory de Saint-Vincent, 1804), MNHN-IM-2013-78206 (Mohéli, Comoros) C Septaria tahitiana Eichhorst, 2016, MNHN-IM-2013-62864 (Moorea, French Polynesia). From left to right: Ventral view, dorsal view, dorsal view without periostracum, side view. Scale bars: 10 $\mathrm{mm}$.

\section{Material and methods}

Sampling. The material was collected during various field missions to the Comoros in 2005, 2006 and 2013, and to Moorea and Tahiti (French Polynesia) in 2014. Additional samples were obtained from the Indo-Pacific region (Reunion Island, Mauritius, Japan (Okinawa) and French Polynesia) (Table 1). 
Table 1. List of specimens used for morphometric and molecular analysis. The identification number is shown for the GenBank sequences and for material deposited at MNHN (MNHN ID). Individual marked $(*)$ could not be included in the morphometric analysis

\begin{tabular}{|c|c|c|c|c|}
\hline Locality & $\begin{array}{l}\text { No of } \\
\text { individuals }\end{array}$ & Year & MNHN ID & GenBank ID \\
\hline
\end{tabular}

Septaria tahitiana Eichhorst, 2016

\begin{tabular}{|c|c|c|c|c|}
\hline \multirow[t]{4}{*}{ Moorea (French Polynesia) } & 4 & 2014 & IM-2013-62862 & MW307286 \\
\hline & & & IM-2013-62863 & MW307287 \\
\hline & & & IM-2013-62864 & MW307288 \\
\hline & & & IM-2013-62866 & MW307284 \\
\hline Tahiti (French Polynesia) & 1 & 2014 & IM-2013-62865 & MW307285 \\
\hline \multicolumn{5}{|c|}{ Septaria porcellana (Linnaeus, 1758) } \\
\hline \multirow[t]{6}{*}{ Okinawa (Japan) } & 6 & 2014 & IM-2013-62867 & MW307278 \\
\hline & & & IM-2013-62868 & MW307279 \\
\hline & & & IM-2013-62869 & MW307280 \\
\hline & & & IM-2013-62870 & MW307281 \\
\hline & & & IM-2013-62871 & MW307282 \\
\hline & & & IM-2013-62872 & MW307283 \\
\hline Okinawa (Japan) & 1 & & & AB477514 \\
\hline
\end{tabular}

Septaria borbonica (Bory de Saint-Vincent, 1804)

\begin{tabular}{lccll}
\hline Mauritius & 2 & 2013 & IM-2013-78197 & MW307275 \\
Reunion Island & 2 & \multirow{2}{*}{2013} & IM-2013-78199 & MW307274 \\
& & & IM-2013-78201*-78202 & MW307273 \\
Moheli (Comoros) & \multirow{2}{*}{3} & IM-2013-78204 & MW307272 \\
& & IM-2013-78206 & MW307276 \\
& & IM-2013-78209 & MW307271 \\
\hline
\end{tabular}

In the field, the specimens were collected on sight. They are, in fact, nearly always visible to the naked eye, living on rocks and boulders along riverbeds. Specimens were fixed in 95\% ethanol. Species were identified based on morphological characters, using the literature (Haynes 2001; Eichhorst 2016b) and by comparison with the collections held at the Muséum national d'Histoire naturelle de Paris (MNHN). Samples from the historical collections of MNHN were also used for morphometric analysis (Table 2). 
Table 2: Dry and wet (in ethanol) specimens used solely for the morphometric analysis

\begin{tabular}{lll}
\hline Locality & Author/Year & $\begin{array}{l}\text { No of } \\
\text { specimens }\end{array}$
\end{tabular}

Septaria tahitiana Eichhorst, 2016

\begin{tabular}{|c|c|c|c|}
\hline Moorea (French Polynesia) & Abdou leg., 2014 & 3 & IM-2013-78194 \\
\hline Moorea (French Polynesia) & Pointier leg., 1985 & 9 & IM-2016-7846 \\
\hline Tahiti (French Polynesia) & Fontaine leg., 2004 & 5 & IM-2016-7847 \\
\hline Tahiti (French Polynesia) & $\begin{array}{l}\text { Gargominy \& } \\
\text { Fontaine leg., } 2004\end{array}$ & 1 & IM-2016-7848 \\
\hline Tahiti (French Polynesia) & $\begin{array}{l}\text { Gargominy \& } \\
\text { Fontaine leg., } 2005\end{array}$ & 6 & IM-2016-7849 \\
\hline Tahiti (French Polynesia) & $\begin{array}{l}\text { Gargominy \& } \\
\text { Fontaine leg., } 2002\end{array}$ & 15 & IM-2016-7850 \\
\hline
\end{tabular}

Septaria porcellana (Linnaeus, 1758)

\begin{tabular}{|c|c|c|c|}
\hline Okinawa (Japan) & $\begin{array}{l}\text { Maeda \& Iida leg., } \\
2014\end{array}$ & 4 & IM-2013-78195 \\
\hline Okinawa (Japan) & $\begin{array}{l}\text { Maeda \& Iida leg., } \\
2014\end{array}$ & 3 & IM-2013-78196 \\
\hline Philippines & Letellier Coll., 1949 & 2 & IM-2016-7851 \\
\hline Philippines & Marche Coll., 1882 & 1 & IM-2016-7852 \\
\hline Palau & Staadt Coll., 1969 & 2 & IM-2016-7853 \\
\hline New Guinea & Staadt Coll., 1969 & 4 & IM-2016-7854 \\
\hline New Hebrides (now Vanuatu) & Soyer Coll., 1969 & 13 & IM-2016-7855 \\
\hline Upolu (Samoa) & Denis Coll., 1945 & 1 & IM-2016-7856 \\
\hline
\end{tabular}

Septaria borbonica (Bory de Saint-Vincent, 1804)

$\begin{array}{llll}\text { Mauritius } & \begin{array}{l}\text { Griffith \& Albrecht } \\ \text { leg.,2013 }\end{array} & 2 & \text { IM-2013-78198 } \\ \text { Mauritius } & \begin{array}{l}\text { Griffith \& Albrecht } \\ \text { leg.,2013 }\end{array} & 4 & \text { IM-2013-78200 } \\ \text { Mauritius } & \begin{array}{l}\text { Griffith \& Albrecht } \\ \text { leg.,2013 }\end{array} & 1 & \text { IM-2016-7857 } \\ \text { Mauritius } & \text { Mission P. Carié, 1918 } & 4 & \text { IM-2016-7858 } \\ \text { Mauritius } & \begin{array}{l}\text { Boivin Coll., 1853; ex } \\ \text { Robillard }\end{array} & 2 & \text { IM-2016-7859 } \\ \begin{array}{l}\text { Mauritius } \\ \text { Mauritius } \\ \text { Mauritius } \\ \text { Reunion Island }\end{array} & \begin{array}{l}\text { Letellier Coll., 1949 } \\ \text { Unknown }\end{array} & 1 & \text { IM-2016-7860 } \\ \text { Staadt Coll., 1969 } & 2 & \text { IM-2016-7861 } \\ \text { Valade leg., 2013 } & 1 & \text { IM-2016-7862 } \\ \text { IM-2013-78203 }\end{array}$


Reunion Island

Reunion Island

Reunion Island

Reunion Island

Reunion Island

Reunion Island

Reunion Island

Reunion Island

Reunion Island

Seychelles

Seychelles

Seychelles

Moheli (Comoros)

Moheli (Comoros)

Moheli (Comoros)

Moheli (Comoros)

Moheli (Comoros)

Moheli (Comoros)

Moheli (Comoros)

Mayotte (Comoros)

Mayotte (Comoros)

Mayotte (Comoros)

Mayotte (Comoros)

Mayotte (Comoros)

Mayotte (Comoros)

Mayotte (Comoros)

Mayotte (Comoros)

Mayotte (Comoros)

Mayotte (Comoros)

Anjouan (Comoros)

Anjouan (Comoros)

Anjouan (Comoros)

Anjouan (Comoros)

Anjouan (Comoros)

Anjouan (Comoros)

Grande Comore (Comoros)

Grande Comore (Comoros)
Don de Mr Alluand, 3

1946

Unknown 4

Unknown 2

Rang Coll., 1826

Mission G. Petit, 19265

Mission G. Petit, 19267

Mission G. Petit, 19267

Unknown 7

Férussac Coll., 18372

Dufo Coll., 1839

Dufo Coll., 1839

Dufo Coll., 1839

Abdou leg., 2013

Abdou leg., 2013

Abdou leg., 2013

Abdou leg., 2005

Abdou leg., 2005

Abdou leg., 2005

Millot Coll., $1954 \quad 1$

Abdou leg., 2006

Abdou leg., 2006

Abdou leg., 2006

Abdou leg., 2006

Jousseaume Coll.,

1921

Abdou leg., 2006

Abdou leg., 2006

Abdou leg., 2006

Abdou leg., 2006

Abdou leg., 2006

Mouron Coll., 1540

Decary Coll., 1921

Abdou leg., 2005

Abdou leg., 2005

Abdou leg., 2005

Abdou leg., 2005

Humblot Coll., 1887

Humblot Coll., 1887
IM-2016-7863

IM-2016-7864

IM-2016-7865

IM-2016-7866

IM-2016-7867

IM-2016-7868

IM-2016-7869

IM-2016-7870

IM-2016-7871

IM-2016-7872

IM-2016-7873

IM-2016-7874

IM-2013-78205

IM-2013-78207

IM-2013-78208

IM-2016-7875

IM-2016-7876

IM-2016-7877

IM-2016-7878

IM-2013-78210

IM-2013-78211

IM-2013-78212

IM-2013-78213

IM-2016-7879

IM-2016-7880

IM-2016-7881

IM-2016-7882

IM-2016-7883

IM-2016-7884

IM-2016-7885

IM-2016-7886

IM-2016-7887

IM-2016-7888

IM-2016-7889

IM-2016-7890

IM-2016-7891

IM-2016-7892 
Morphometric analysis and reproductive anatomy. A total of 234 specimens, representing the three species (154 S. borbonica, $36 \mathrm{~S}$. porcellana and $44 \mathrm{~S}$. tahitiana), were analysed using morphometric analysis (Tables 1 and 2). The length (L), width (W) and height (H) of each shell were measured using a $0.03 \mathrm{~mm}$ precision calliper (Fig. 2). The ratios L/W and L/H were calculated and used as quantitative variables to avoid any bias that could be introduced by an allometric effect, as well as their average, minima and maxima for each species. The KruskalWallis $(\mathrm{KW})$ test, a non-parametric statistical test, alternative to the ANOVA, was performed, using XLSTAT (Addinsoft 2020) to explore differences among the three nominal species and complement the morphometric analysis with, as null hypothesis H0: there is no significant difference between the nominal taxa studied, and as alternative hypothesis Ha: at least one nominal taxon is significantly different from the others. The $\mathrm{KW}$ test was used for both the $\mathrm{L} / \mathrm{H}$ ratio and the $\mathrm{L} / \mathrm{W}$ ratio. In order to identify which taxon is significantly different from the others, Dunn's multiple pairwise comparisons procedure was used.

Haynes (2001) was followed here for the analysis of the reproductive system.
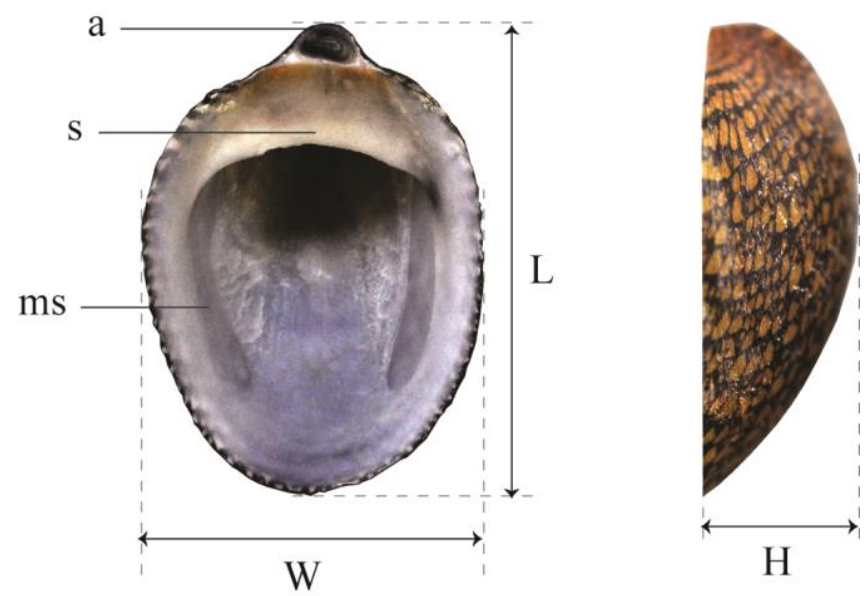

Figure 2. Shell measurement protocol. H height L length $\mathrm{W}$ width. a apex, ms muscle scar, $\mathrm{s}$ septum.

COI analysis. A fragment of the mitochondrial gene coding for the first subunit of Cytochrome oxydase I (COI) was sequenced for 18 individuals (7 S. borbonica, 6 S. porcellana and $5 S$. tahitiana) (Table 1). DNA extraction, PCR and quality control were performed according to the protocol used by Abdou et al. (2017). Sequences were aligned using Muscle (Edgar 2004). Phylogenetic analysis was performed with the Bayesian inference (BI) method, under MrBayes 3.2 (Ronquist et al. 2012) partitioning by codon position with 5 million generations and sampling every 100 generations, and $10 \%$ of trees were eliminated as burnin after checking for convergence. The HKY +I substitution model was selected by jModelTest 2.1.1 (Darriba et al. 2012). Intra- and interspecific p-distances were estimated in the software MEGA 7 (Kumar et al. 2016). Three sequences were taken from GenBank, one of S. porcellana (AB477514), one of Neritilia rubida (AB102712) and one of Neritina pulligera (AB477502). The last two served as outgroup. All sequences have been deposited in Genbank (accession numbers MW307271-MW307288).

For $S$. porcellana and S. borbonica, shared haplotypes were searched using DnaSP v5.1 software (Librado \& Rozas 2009). To visualize the genealogical relationships between haplotypes and their geographic distribution, a haplotype network was constructed with the Median-Joining method implemented in Network v10.0.0.0 (Bandelt et al. 1999), using default settings.

\section{Results}


Morphometric analysis and reproductive anatomy. The averages, minima and maxima of the measurements are shown in Table 3. The cloud of points in Figure 3 graphically represents the $\mathrm{L} / \mathrm{W}$ and $\mathrm{L} / \mathrm{H}$ ratios. It shows that the $S$. tahitiana individuals are at the top of the graph with a high L/W ratio (average 1.42). Individuals belonging to $S$. porcellana are leftmost in a low L/H ratio (average 2.81), but they are largely mixed with specimens of $S$. borbonica. The representatives of the latter occupy a central position in relation to the two axes and cover practically the entire space of the cloud. Two samples from Mayotte, supposed to belong to $S$. borbonica (Fig. 4A, B), are distinguished from all others of the same taxon. They are indicated by arrows in Figure 3.

Table 3: Averages, minima and maxima calculated for L / W and L / $\mathrm{H}$ ratios

\begin{tabular}{llll}
\hline & S. borbonica & S. porcellana & S. tahitiana \\
\hline Number of samples & 154 & 36 & 44 \\
L/W: Av(Min; Max) & $\mathbf{1 . 3 7}(1.23 ; 1.77)$ & $\mathbf{1 . 2 7}(1.17 ; 1.34)$ & $\mathbf{1 . 4 2}(1.21 ; 1.66)$ \\
L/H: Av(Min; Max) & $\mathbf{2 . 8 4}(2.29 ; 3.76)$ & $\mathbf{2 . 8 1}(2.47 ; 3.22)$ & $\mathbf{3 . 3 7}(3.71 ; 3.77)$ \\
\hline
\end{tabular}

For the KW test applied to $\mathrm{L} / \mathrm{H}$ and to $\mathrm{L} / \mathrm{W}$, the calculated $\mathrm{p}$-value is lower than the significance level alpha in both cases $(\mathrm{p}<0.0001 ; \alpha=0.05)$. The Dunn's multiple pairwise comparisons procedure, concerning the $\mathrm{L} / \mathrm{H}$ variable, distinguishes two significantly different groups, one represented by Septaria tahitiana, and the other by S. borbonica and S. porcellana. With regard to the variable $\mathrm{L} / \mathrm{W}$, three groups are distinguished, represented by the three nominal taxa.

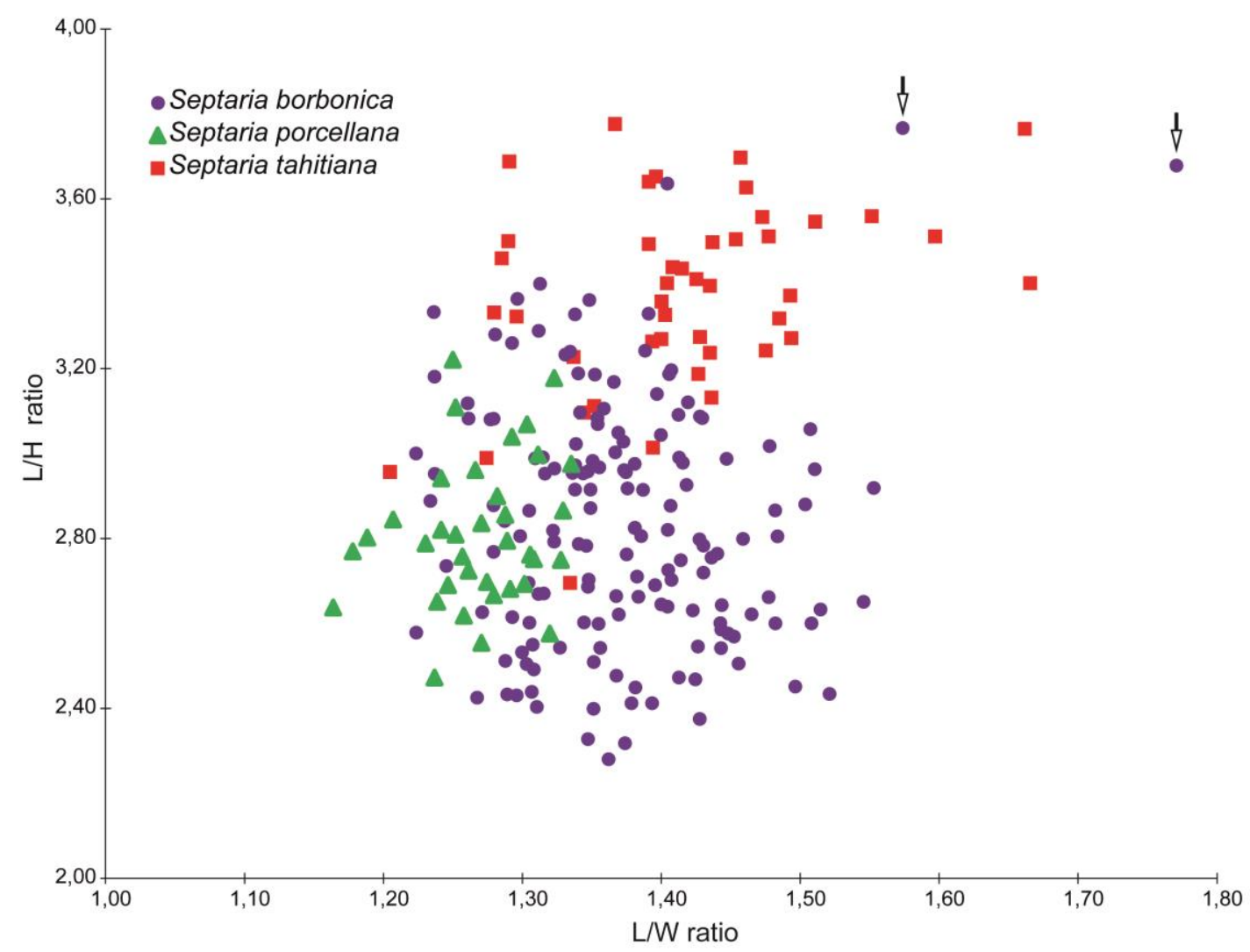

Figure 3: Cloud of points representing the $\mathrm{L} / \mathrm{W}$ and $\mathrm{L} / \mathrm{H}$ ratios of Septaria borbonica, S. porcellana and S. tahitiana. 
According to Haynes (2001), males of the three taxa do not produce spermatophores but, while the female of S. tahitiana has a dorsal spermatophore sac, those of S. porcellana and $S$. borbonica have a remnant ventral spermatophore sac.

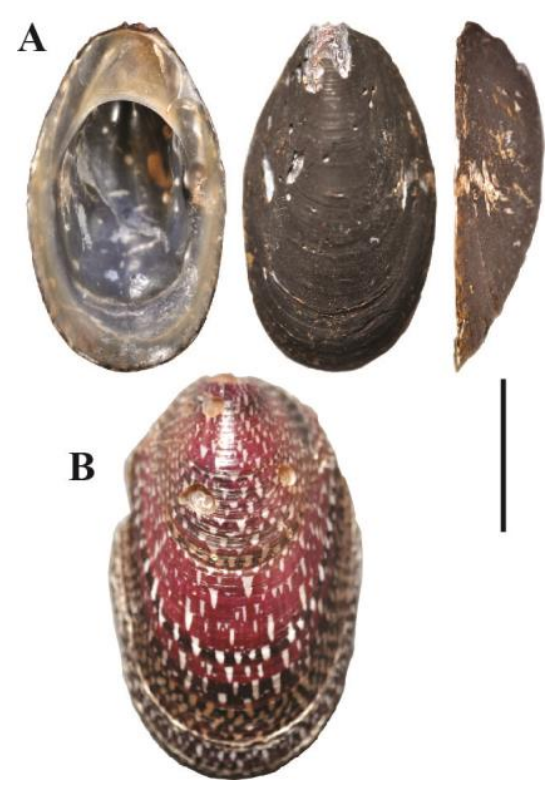

Figure 4. A, B. Samples supposed to belong to Septaria borbonica but for which the identification is doubtful. A MNHN-IM-2013-78211 (Mayotte, Comoros) B MNHN-IM-201378212 (Mayotte, Comoros), dorsal view without periostracum. Scale bar: $10 \mathrm{~mm}$.

COI analysis. Partial sequences of 615 base pairs of the COI gene were analysed for 19 individuals. Seven sequences belong to S. borbonica (Comoros, $\mathrm{N}=3$; Mauritius, $\mathrm{N}=2$ and Reunion Island, $\mathrm{N}=2$ ), five to $S$. tahitiana (Moorea, $\mathrm{N}=4$ and Tahiti, $\mathrm{N}=1$ ) and seven to S. porcellana (Okinawa, Japan), including one sequence recovered from GenBank (AB477514, Table 1). The Bayesian inference discriminates $S$. tahitiana compared to the other two taxa with a posterior probability (PP) of 1, but $S$. porcellana and $S$. borbonica are in the same clade (Fig. 5). The mean pairwise inerspecific p-distances for COI for the three taxa varied from $4.71 \%$ to $5.05 \%$, whereas the mean intraspecific p-distances varied from $0.33 \%$ to $1.40 \%$ (Table 4 ).

The haplotype network (Fig. 6) shows two separate haplotype groups, corresponding to samples of S. borbonica from the western Indian Ocean and to S. porcellana from the Pacific Ocean. No haplotypes are shared by the two haplogroups. The seven samples from the Indian Ocean involve 5 haplotypes, one of which is shared by samples from Mauritius, Reunion Island and Comoros. The seven samples from the Pacific Ocean involve 3 haplotypes, one of which is shared by 5 individuals from Japan.

Table 4: COI p-distances between Septaria borbonica, S. porcellana and S. tahitiana

\section{S. borbonica S. porcellana S. tahitiana}

\begin{tabular}{llll}
\hline S. borbonica & $0.47 \%$ & & \\
S. porcellana & $\mathbf{1 . 4 0 \%}$ & $0.33 \%$ & \\
S. tahitiana & $\mathbf{5 . 0 5 \%}$ & $\mathbf{4 . 7 1 \%}$ & $0.59 \%$ \\
\hline
\end{tabular}




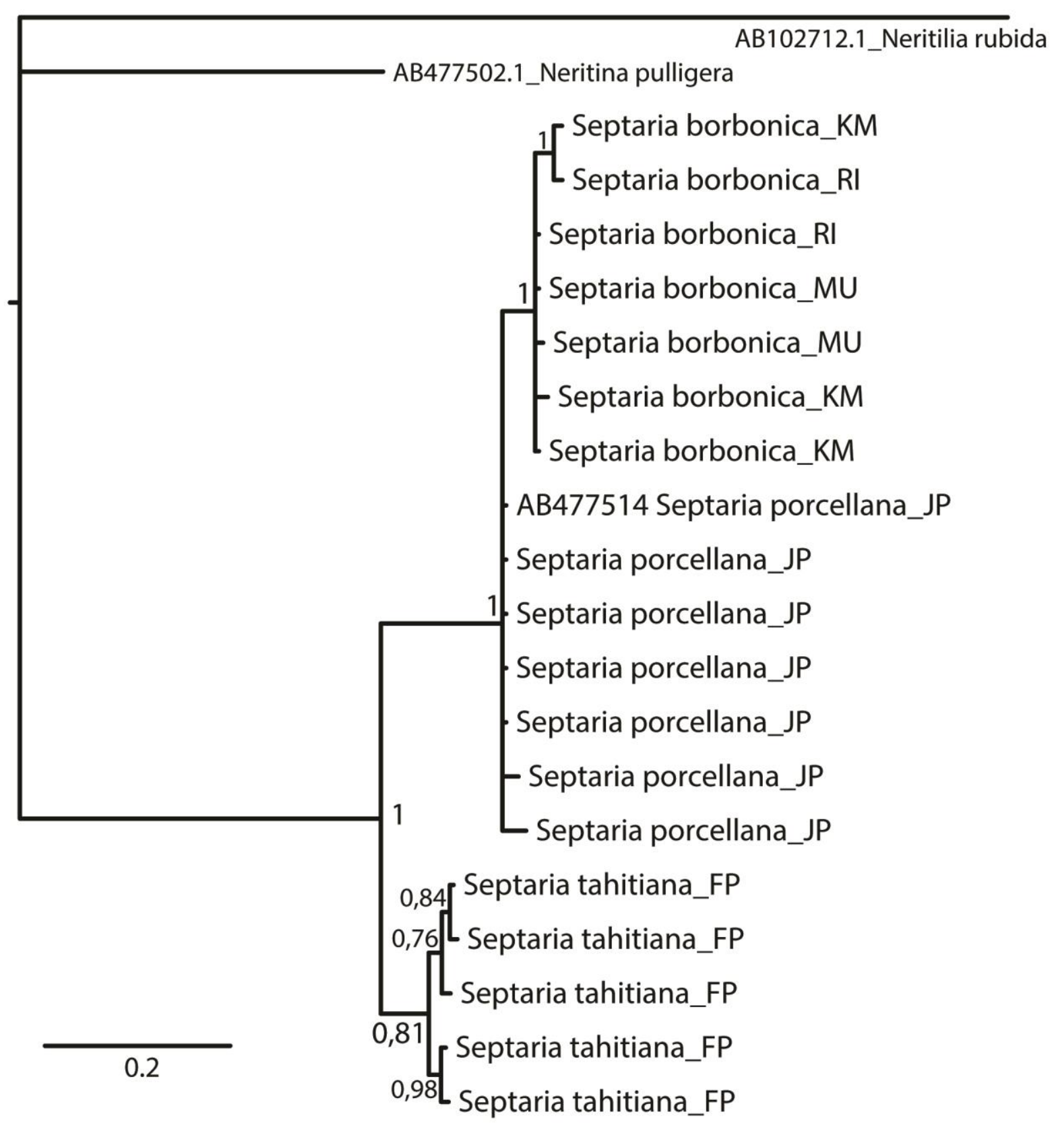

Figure 5. Bayesian analysis of the gene of the sub-unit 1 of the Cytochrome oxydase (COI). FP French Polynesia, JP Japan, KM Comoros, MU Mauritius, RI Reunion Island.

\section{Discussion}

The L/W ratio of $S$. tahitiana (Table 3) indicates a narrower width than length, and therefore a more tapered shape than the other two taxa. In Figure 3, S. tahitiana is distinguished from the other two taxa even though there is a slight overlap. Overall, morphologically speaking, the shell of $S$. borbonica is slightly flatter and less rounded than that of $S$. porcellana (Table 3 ), as previously reported by Haynes (2001), but this is not really obvious. The morphological similarity between these two taxa is such that Eichhorst (2016b: 816) claimed that it is impossible to distinguish them "using just shell sharpe, colour and pattern. Even the opercula are similar. For these two species, locality is key to proper identification". Indeed, the shells of the two taxa have similar classical 
patterns on the outside, roughly triangular (Fig. 1A, B). This morphotype is the only one found in all observed S. borbonica shells from several islands in the Indian Ocean (Fig. 7C-H). In contrast, $S$. porcellana, which until now has never been reported in the western Indian Ocean, shows at least two additional very unusual patterns in (Fig. 7A, B), consisting of more or less thick lines radiating from the apex. Furthermore, the KW test supports the Ha hypothesis that at least one taxon is significantly different from the other two. Indeed, insofar as the calculated p-value $\mathrm{p}<0.0001<\alpha=0.05$, it is advisable to reject the null hypothesis $\mathrm{H} 0$, and to retain the alternative hypothesis Ha. The multiple pairwise comparisons using Dunn's procedure, for the $\mathrm{L} / \mathrm{H}$ variable, clearly separates $S$. tahitiana from $S$. porcellana and $S$. borbonica gathered in the same group.
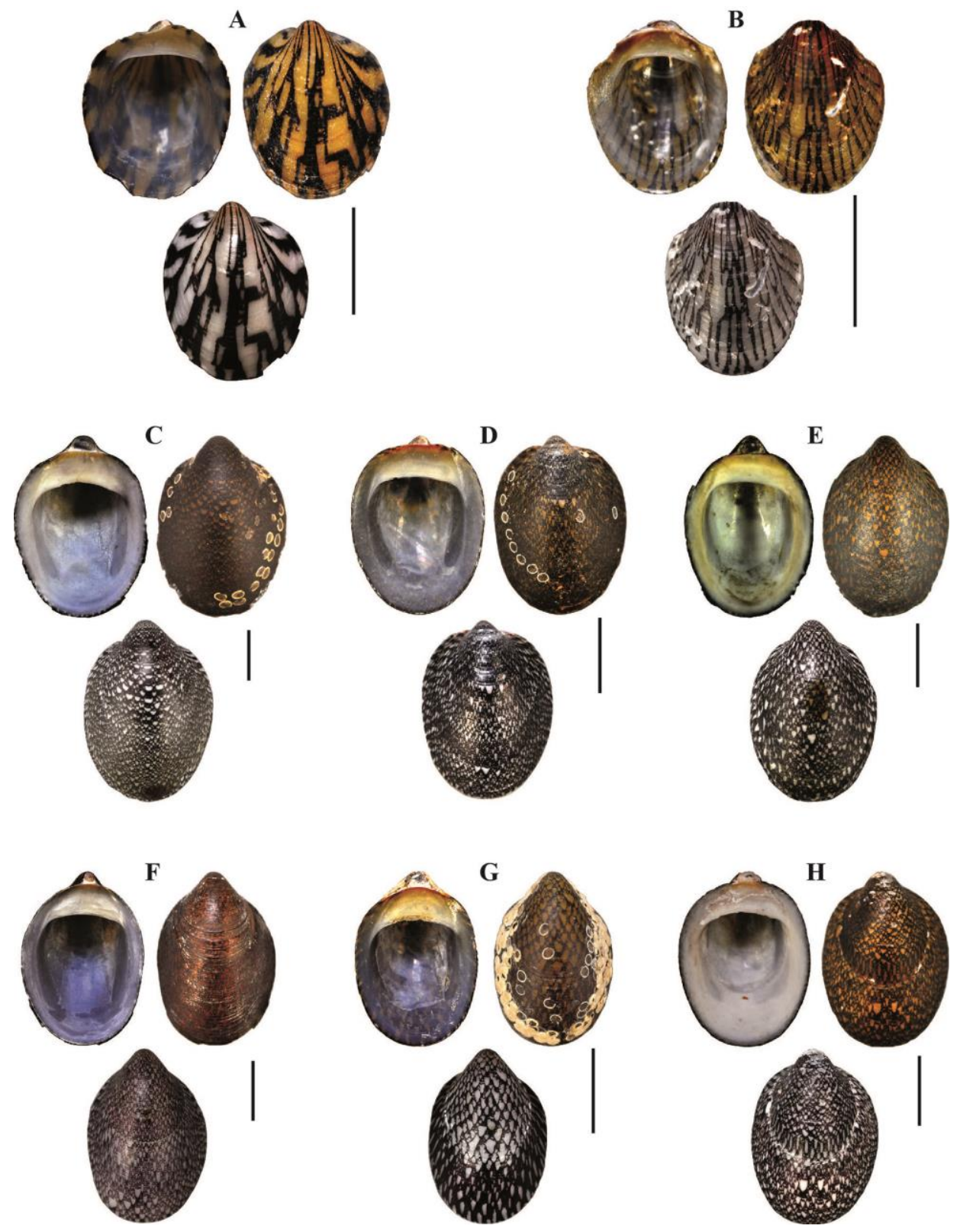

Figure 7. A, B. Two other different external patterns of the shell, found in Septaria porcellana. A. MNHN-IM-2013-62872 (Okinawa, Japan) B. MNHN-IM-2013-62867 (Okinawa, Japan). CH. Samples of $S$. borbonica from different islands in the Indian Ocean have a common external pattern. C. MNHN-IM-2016-7863 (Reunion Island) D. MNHN-IM-2016-7857 (Mauritius) E. MNHN-IM-2016-7874 (Seychelles) F. MNHN-IM-2016-7880 (Mayotte, Comoros) G. MNHNIM-2016-7887 (Anjouan, Comoros) H. MNHN-IM-2016-7892 (Grande-Comore, Comoros). Dorsal view without periostracum, below. Scale bars: $10 \mathrm{~mm}$. 
Concerning genital anatomy, Haynes (2001) indicated that S. tahitiana and S. porcellana are sexually dimorphic, with males being significantly smaller than females. However, while females of $S$. tahitiana have a dorsal spermatophore sac, which is a plesiomorphic character, females of $S$. porcellana and $S$. borbonica have the same synapomorphy, viz a ventral (vestigial) spermatophore sac, the evolution being towards a simplification of the anatomy of the reproductive system (Haynes 2001).

The mean p-distances calculated for COI (Table 4) show a clear separation of S. tahitiana from $S$. borbonica $(5.05 \%)$ on the one hand, and from S. porcellana $(4.71 \%)$ on the other hand. The distance of $1.40 \%$ between $S$. porcellana and $S$. borbonica is very small raising doubts whether these taya represent different species. For the family Neritidae, mean intraspecific genetic p-distance for COI would be less than 2.96\% (Frey \& Vermeij 2008) whereas Abdou et al (2017) suggested that mean sequence divergences $>3 \%$ indicate interspecific differences. The distance of $1.40 \%$ is rather consistent with an intraspecific variation. Moreover, the cladogram in figure 5 shows clearly, on the one hand, that $S$. tahitiana forms a clade clearly separated from the other two taxa and, on the other hand, that $S$. porcellana does not constitute a clade dissociated from $S$. borbonica. There is therefore a convergence between the COI and morpho-anatomical data for these two taxa. Thus $S$. porcellana would rather be a polytypical species and $S$. borbonica one of its populations, probably in the process of speciation, due to its geographical isolation, as shown by the network of haplotypes (Fig. 6).

Septaria borbonica

Septaria porcellana

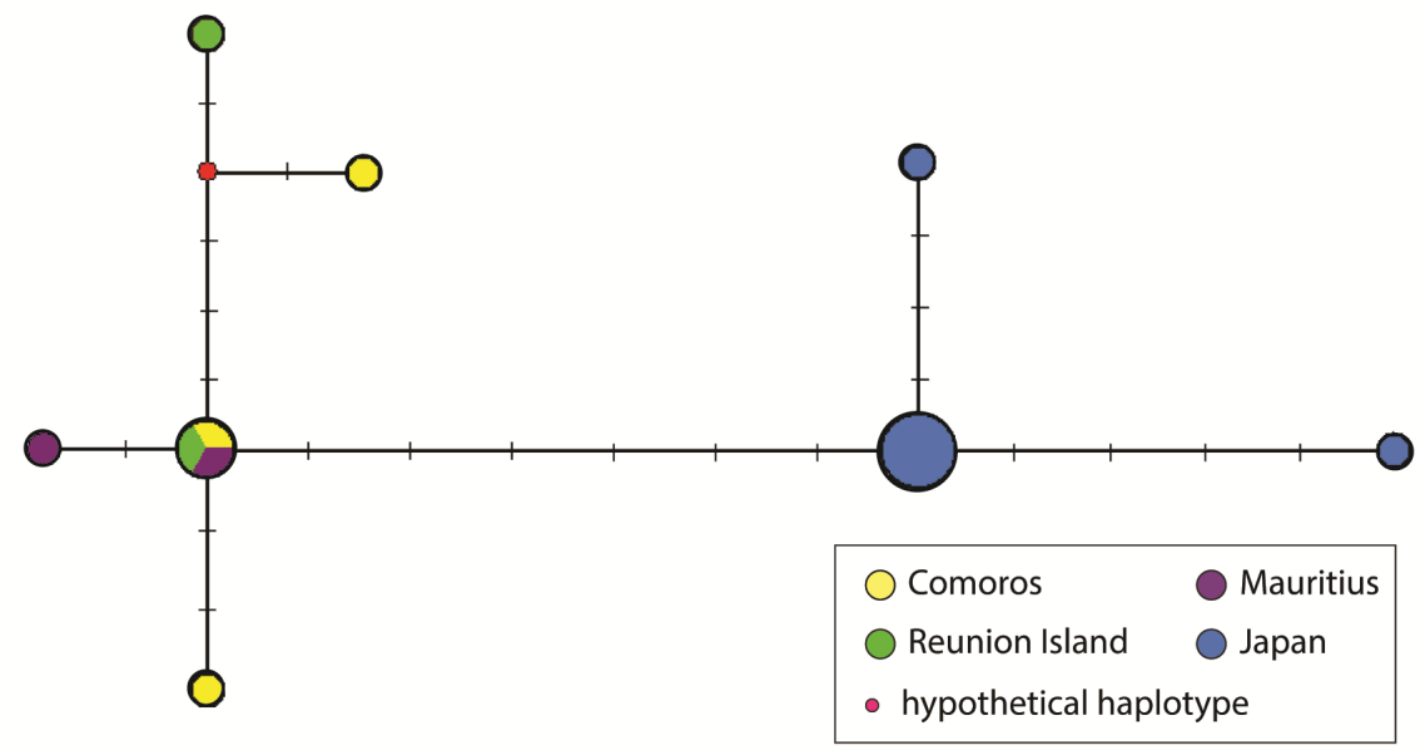

Figure 6. Haplotype network of the nominal species Septaria borbonica and S. porcellana according to the median-joining method. The circles are proportional to the frequency of occurrence, the number of mutations is indicated on the branches by dashes.

I have adopted an integrative congruence approach (DeSalle et al. 2005; Padial et al. 2010) according to which if two groups are distinguishable by at least two independent datasets, they belong to two different species. Three datasets were used in the present work, viz shell morphometry (Fig. 3), reproductive anatomy based on Haynes (2001) and COI sequences (Fig. 5). Table 5 summarizes these three datasets and facilitates comparisons. Based on these three datasets S. tahitiana could be consistenly differentiated from the other two taxa. In contrast, neither shell morphometrics, nor reproductive anatomy or COI sequences were able to distinguish between S. porcellana and S. borbonica. Therefore, it would be more logical to consider S. borbonica as a 
subspecies of $S$. porcellana. Its nomenclatural transcription thus becomes Septaria porcellana borbonica (Bory de Saint-Vincent, 1804).

Table 5: comparison of the three taxa against the data sets

\begin{tabular}{|c|c|c|c|}
\hline & S. borbonica & S. porcellana & S. tahitiana \\
\hline Morphology & \multicolumn{2}{|c|}{$\begin{array}{l}\text { - Overall similar shell shape } \\
\text { - Grouped by KW test relative to the variable } \\
\text { L/H, but separated with respect to L/W }\end{array}$} & $\begin{array}{l}\text { - More tapered shell shape } \\
\text { - Separated from the other } \\
\text { two taxa by KW test }\end{array}$ \\
\hline $\begin{array}{l}\text { Genital } \\
\text { anatomy }\end{array}$ & \multicolumn{2}{|c|}{ - Ventral spermatophore sac: a synapomorphy } & $\begin{array}{l}\text { - Dorsal spermatophore sac: } \\
\text { a plesiomorphy }\end{array}$ \\
\hline COI & \multicolumn{2}{|c|}{$\begin{array}{l}\text { - Very small p-distance between the two taxa } \\
(=1.40 \%)\end{array}$} & $\begin{array}{l}\text { - Large p-distance from } \\
\text { other taxa }(>3 \%)\end{array}$ \\
\hline $\begin{array}{l}\text { Distribution } \\
\text { range }\end{array}$ & $\begin{array}{l}\text { - Known only in the } \\
\text { Western Indian Ocean }\end{array}$ & $\begin{array}{l}\text { - Known in the } \\
\text { Western Pacific and } \\
\text { Eastern Indian } \\
\text { Oceans }\end{array}$ & $\begin{array}{l}\text { - Only occurs in French } \\
\text { Polynesia }\end{array}$ \\
\hline
\end{tabular}

As the Indo-Australian archipelago, the largest known and documented Indo-Pacific Barrier (Abdou et al. 2019), cannot be invoked in this case to explain the geographical isolation of Septaria p.porcellana borbonica, there must be another barrier within the Indian Ocean itself. Indeed, according to Haynes (2001) and Eichhorst (2016b), Septaria p. porcellana occurs in the western Pacific and eastern Indian Ocean (southern India, Andaman Islands, Indonesia), so it has not been impacted by fluctuations in the Great Indo-Pacific Barrier. The largest multi-species phylogeographic study in the Indo-Pacific, based on 56 species from 4 phyla and 27 families, to test biogeographic hypotheses, was conducted by Crandall et al. (2019). Among the five putative filtering barriers tested, there is one between the Western Indian Ocean Province (including Madagascar, the Mascarenes, Seychelles and Comoros, as defined by Briggs \& Bowen (2012)), and the entire region formed by the East Indian Ocean and the West Pacific Ocean.

In addition, two specimens (Fig. 4A, B) supposed to belong to $S$. borbonica (indicated by arrows in Figure 3) are well off-centre with respect to the cloud of points representing the taxon. These are two samples from Mayotte, laterally compressed, and whose shell patterns correspond neither to those of $S$. borbonica, nor to those of $S$. porcellana, but for which molecular sequences are not available. Eichhorst (2016b: 815) has reported an unconventional morphe of this taxon "purplish-red shell with an elongate pattern collected [...] on Mayotte". It is possible that these samples belong to $S$. tesselata (Lamarck, 1816), a taxon with a similar morphological profile. This taxon is and $S$. borbonica are the only two Septaria taxa reported from the Western Indian Ocean, among the 14 documented species of the genus.

\section{Conclusion}

This study confirms the status of $S$. tahitiana as a valid species and interprets $S$. borbonica as subspecies of $S$. porcellana. To better understand the phylogeography of this species, it would be interesting to date the separation of the two populations, and to determine the barrier, intermittent or not, preventing or limiting genetic exchanges between them. In addition, targeted sampling in Mayotte would be necessary to confirm or refute the suspected presence of $S$. tesselata. 


\section{Acknowledgements}

FRE BOREA and USR 3278 CRIOBE funded the field mission of the author to Moorea in 2014. DNA extraction and PCR were performed on the technical platform of the Molecular Systematic Service of the MNHN. We thank K. Maeda \& M. Iida; O. Gargominy \& B. Fontaine, P. Valade, O. Griffith \& C. Albrecht, who provided us with samples from Japan, Tahiti, Reunion Island and Mauritius respectively. Thanks also to Gaël Denys, Clara Lord and Philippe Keith for their technical help. Finally, we would like to thank Thierry Backeljau and an anonymous reviewer, whose recommendations have allowed us to improve this article.

\section{References}

Abdou, A., Keith, P. \& Galzin, R. (2015) Freshwater neritids (Mollusca: Gastropoda) of tropical islands: amphidromy as a life cycle, a review. Revue d'Écologie (Terre et Vie), 70 (4), 387397. http://hdl.handle.net/2042/56931

Abdou, A., Galzin, R., Lord, C., Denys, G. \& Keith, P. (2017) Revision of the species complex 'Neritina pulligera' (Gastropoda: Cycloneritimorpha: Neritidae) using taxonomy and barcoding. Vie et Milieu - Life \& Environment, 67 (3-4).

Abdou, A., Lord, C., Keith, P. \& Galzin, R. (2019) Phylogéographie de Neritina stumpffi Boettger, 1890 et Neritina canalis Sowerby, 1825 (Gastropoda, Cycloneritida, Neritidae). Zoosystema, 41 (12), 237-248. https://doi.org/10.5252/zoosystema2019v41a12. http://zoosystema.com/41/12

Addinsoft (2020) XLSTAT statistical and data analysis solution. Paris, France. https://www.xlstat.com

Bandelt, H.-J., Forster, P. \& Röhl, A. (1999) Median-joining networks for inferring intraspecific phylogenies. Molecular Biology and Evolution, 16, 37-48. https://doi.org/10.1093/oxfordjournals.molbev.a026036

Bory de Saint-Vincent, J. B. G. M. (1804) Voyage dans les quatre principales îles des mers d'Afrique, fait par ordre du gouvernement, pendant les années neuf et dix de la République (1801 et 1802). Avec l'histoire de la traversée du Capitaine Baudin jusqu'au Port-Louis de l'Ile Maurice. Tome 1. - pp. I-XV [= 1-15], [1], 1-412, P1. 1-58. Paris. (Buisson).

Briggs, J.C., \& Bowen, B.W. (2012) A realignment of marine biogeographic provinces with particular reference to fish distributions. Journal of Biogeography, 39 (1), 12-30. https://doi.org/10.1111/j.1365-2699.2011.02613.x

Bunje, P.M.E. \& Lindberg, D.R. (2007) Lineage divergence of a freshwater snail clade associated with post-Tethys marine basin development. Molecular Phylogenetics and Evolution, 42 (2), 373-387.

Crandall, E.D;, Taffel, J.R. \& Barber, P.H. (2010) High gene flow due to pelagic larval dispersal among South Pacific archipelagos in two amphidromous gastropods. Heredity, 104, 563572.

Crandall, E.D. et al. (2019) The molecular biogeography of the Indo-Pacific: Testing hypotheses with multispecies genetic patterns. Global Ecology and Biogeography, 28 (7), 943-960. https://doi.org/10.1111/geb.12905

Darriba, D., Taboada, G.L., Doallo,R. \& Posada, D. (2012) jModelTest 2: more models, new heuristics and parallel computing. Nature Methods, 9, 772.

DeSalle, R., Egan, M.G. \& Siddal, M. (2005) The unholy trinity: taxonomy, species delimitation and DNA barcoding. Philosophical Transactions of the Royal Society Soc B, 360, 19051916. https://doi.org/10.1098/rstb.2005.1722

Edgar, R.C. (2004) MUSCLE: multiple sequence alignment with high accuracyand high throughput. Nucleic Acids Research, 32, 1792-1797. 
Eichhorst, T.E. (2016a) Neritidae of the World. Vol. 1. Harxheim. ConchBooks. 694 pp.

Eichhorst, T.E. (2016b) Neritidae of the World. Vol. 2. Harxheim. ConchBooks. 672 pp.

Férussac, J. B. L. d'Audebard de \& A. E. J. P. F. d'Audebard de Férussac. (1807) Essai d'une méthode conchyliologique Appliquée aux Mollusques fluviatiles et terrestres d'après la considération de l'animal et de son Test. Nouvelle édition augmentée d'une synonymie des espèces les plus remarquables, d'une table de concordance systématique de celles qui ont été décrites par Géoffroy, Poiret et Draparnaud, avec Müller et Linné, et terminée par un catalogue d'espèces observées en divers lieux de la France. Delance, Paris. xvi +142 pp.

Frey, M.A. \& Vermeij, G.J. (2008) Molecular phylogenies and historical biogeography of a circumtropical group of gastropods (Genus: Nerita): implications for regional diversity patterns in the marine tropics. Molecular Phylogenetics and Evolution, 48,1067-1086. DOI: 10.1016/j.ympev.2008.05.009.

Haynes, A. (2001) A revision of the genus Septaria Férussac. 1803 (Gastropoda: Neritimorpha). Annalen des Naturhistorischen Museums in Wien. Serie B für Botanik und Zoologie, 103, 177-229.

Kano, Y., Chiba S. \& Kase T. (2002) Major adaptive radiation in Neritopsine gastropods estimated from $28 \mathrm{~S}$ rRNA sequences and fossil records. Proceedings of the Royal Society $B, 269,2457-2465$. doi: 10.1098/rspb.2002.2178.

Kumar, S., Stecher, G. \& Tamura, K. (2016) MEGA7: Molecular Evolutionary Genetics Analysis version 7.0 for bigger datasets. Molecular Biology and Evolution, 33, 1870-1874.

Lamarck [J.B.P.A. de M. de]. (1816) Tableau encyclopédique et méthodique des trois règnes de la nature, Mollusques et polypes divers. Part 23 [Livraison 84, 14 December 1816], Tome 3, pp. 1-16, pls. 391-431, 431 bis, 431 bis*, 432-488, Paris: Vve Agasse.

Librado, P. \& Rozas, J. (2009) DnaSP v5: A software for comprehensive analysis of DNA polymorphism data. Bioinformatics, 25, 1451-1452. https://doi.org/10.1093/bioinformatics/btp187.

Linnaeus, C. (1758) Systema Naturae per regna tria naturae, secundum classes, ordines, genera, species, cum characteribus, differentiis, synonymis, locis. Editio decima, reformata [10th revised edition], vol. 1: 824 pp. Laurentius Salvius: Holmiae.

Liu, H.T.T. \& Resh, V.H. (1997) Abundance and microdistribution of freshwater gastropods in three streams of Moorea. French Polynesia. Annales de Limnologie, 33, 235-244.

McDowall, R. M. (2007) On amphidromy, a distinct form of diadromy in aquatic organisms. Fish and Fisheries, 8, 1-13. https://doi.org/10.1111/j.1467-2979.2007.00232.x

Padial, J. M., Miralles, A., De la Riva, I., Vences, M. (2010) The integrative future of taxonomy. Frontiers in Zoology, 7, 16. https://doi.org/10.1186/1742-9994-7-16

Pointier, J.P. \& Marquet, G. (1990) Taxonomy and distribution of freshwater mollusks of French Polynesia. Venus, 49 (3), 215-231.

Récluz, C. A. (1843) Descriptions of various species of Navicella, collected by Mr Cuming in the Philippine Islands. Proceedings of the Zoological Society of London, 10, 154-160.

Reeve, L.A. (1856) Monograph of the genus Navicella. Conchologia Iconica, 9.

Resh, V.H., Barnes, J.R. \& Craig, D.A. (1990) Distribution and ecology of benthic invertebrates in the Opunohu river catchment. Moorea. French Polynesia. Annales de Limnologie, 26,195-214.

Resh, V.H., Barnes, J.R., Benis-Steger, B. \& Craig, D. A. (1992) Life-history features of some invertebrates in a French Polynesian stream. Studies on Neotropical Fauna and Environment, 27,145-153.

Ronquist, F., Teslenko, M., van der Mark, P., Ayres, D.L., Darling, A., Höhna, S., Larget, B., Liu, L., Suchard, M.A., Huelsenbeck, J.P. (2012) MrBayes 3.2: Efficient Bayesian Phylogenetic Inference and Model Choice across a Large Model Space. Systematic Biology, 61 (3), 1539-542. https://doi.org/10.1093/sysbio/sys029 